\title{
A TYPOLOGY OF MALE CONSUMERS ON THE MEN'S ELEGANT FASHION MARKET: CASE STUDY OF POLAND
}

\author{
Grzegorz Maciejewski ${ }^{\bowtie}$, Dawid Lesznik \\ University of Economics in Katowice, Poland
}

\begin{abstract}
The authors of the presented article conducted primary research among contemporary gallants, aiming to identify consumer types within the niche of elegant men's clothing, including possible dandies. In the conducted study, online surveys were posted on internet forums and thematic groups focused on Polish male smart dressers. As many as 30\% of respondents considered themselves as dandies, and three types of customers were distinguished: exacting sartorialists, low-budget gallants and phonies. The difference between the first two is mainly due to disparities in purchasing budgets. Phonies, on the other hand, appear to be superficial in purchase decisions, perhaps gaining interest in an elegant style only as a temporary whim. The results will prove useful for brands in the men's elegance segment, broadly highlighting the in-depth characteristics of different customer groups. Moreover, contrary to the subject literature, the research shows that dandyism is still a lively trend.
\end{abstract}

Key words: consumer behaviour, men's fashion, trend, dandyism, sartorialism, gallant

JEL codes: C38, E21, M31

\section{INTRODUCTION}

Dandyism arose as a philosophical and social trend in 19th-century Europe, mainly in France and England. It was an expression of rebellion against the omnipresent mediocrity of social life, especially in terms of clothing [Howells 1996, p. 25]. The dandy always had an impeccable appearance, and his clothes, by definition, had to be elegant [Visser 2011]. What is more, among dandies, elegant clothing grew even to transcendent values, such as a factor that transforms a person [D'Hamilton 2015, Maciejewski and Lesznik 2020]. Therefore, dandyism was not only a distinctive way of dressing in order to arouse interest, but a philosophy based on an aesthetic scale, to some extent a specific fashion style based on symbolic values [Smith 1974, Ma et al. 2012]. It was such an inner sense of beauty and harmony that was the driving force of the purely male trend of dandyism [Rhodes 1928, Gill 2007].

Although dandies aroused emotions in salons [and that was their unofficial purpose], they were generally characterized as phlegmatic and as truly cold-blooded English [Przybylski 1986]. Albert Camus inscribed dandyism in the lineage of his L'Homme révolté, as the most original image of romanticism: a rebel spirit based only on a staged pose. The latter is associated with the concept of sprezzatura, i.e. creating an appearance of nonchalance and full naturalness by the 
dandy in the eye of the beholder. However, it is only a facade for the trained and fully conscious breaking of certain rules of elegance [Goeller 2014].

Beau Brummel [1778-1840] is considered as the ancestor of all dandies, even though some authors indicate that dandyism had its beginning even earlier. Although Brummel exaggerated the importance of perfectly matching clothes and had an obsessive attention to detail, he warned against falling into falsehood and artificiality [Nalewajska 2010, pp. 14-15, Gautrand 2011]. It can therefore be said that dandies have always been well-informed and very demanding consumers, attached to their tailors, to some extent almost the first prosumers [Szul 2013]. For this reason, it is said that certain clothes or accessories are sartorial - high quality, in line with the standards of classic elegance, and traditional tailoring (from Latin sartorius as a term for a product related to tailoring) [WWW1].

In fact, it is true that in order to truly understand a dandy, one must become a dandy oneself [OkuliczKozaryn 1995, p. 15]. In the course of research on contemporary gallants, the authors tried to answer the following research questions:

H1. Is it still possible to identify dandies in the 21 st century according to the classical definition of this trend?

$\mathrm{H} 2$. What factors and features of elegant products do contemporary gallants (used here as another term for dandies) pay attention to when making purchasing decisions?

H3. What is the typology of contemporary gallants as consumers? Is it possible to identify new types of customers within this niche that are characteristic of the postmodern era?

\section{LITERATURE REVIEW}

Dandies should be distinguished from other types of gallants, who were not as highly committed to the creation of elegant fashion canons [Okulicz-Kozaryn, p. 14]. In the literature, it is proposed to differentiate between three other types that coexisted in the days of dandyism: flâneur, the fashionable and gentlemen. The first can be considered a cool and withdrawn halfdandy, an anonymous observer of the lives of others, wandering aimlessly, inherently passive in his beha- viour, trying to avoid people and drawing attention to himself [Burton 2017, pp. 52-58]. The fashionable, in turn, was slavishly committed to elegance, to the point of exaggeration [Okulicz-Kozaryn, p. 13]. Only the gentlemen characterization has survived to modern times, albeit in a somewhat changed sense.

There are some difficulties in distinguishing between a dandy and a gentleman. It is indicated that a gentleman was enslaved by good manners and conventions, which significantly limited his choices in terms of clothing [Skrucha 2012]. Meanwhile, the dandy, through his innate arrogance, created fashion canons himself and was not subordinate to any rules, so he could constantly break them as to arouse interest around himself [Okulicz-Kozaryn, p. 38]. Based on previous research, the authors also propose the concept of a modern sartorialist - a representative of dandyism that is "stripped" from the philosophical foundations of this trend [Maciejewski and Lesznik 2020]. To sum up, the differences between the dandy and other types of gallants are presented in the form of a diagram in Figure 1.

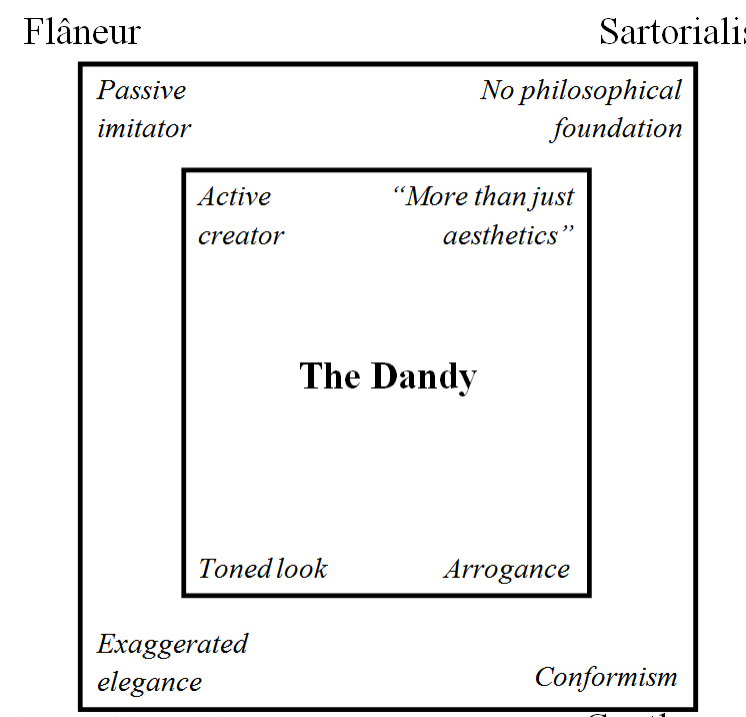

The Fashionable Gentleman

Fig. 1. Dandy vs. other types of gallants

Source: Authors' own work.

The literature on the topic of dandyism is quite poor and focuses mainly on the historical image of this trend within the framework of a philosophical doctrine whose time has passed, while in the third millennium 
only scattered by-products or ethnic currents of dandyism are present [Ferrero-Regis 2017, Khabeer 2017]. While dandyism may have lost its characteristic worldview foundation, the liking for elegance among men is invariably alive also in the 21 st century - dandyism itself may historically be the root of narcissistic metrosexuality as a male seduction strategy [Gębala 2008, Halligan 2011, Maciejewski 2012, Gheorghe 2015]. Dandyism as a philosophical trend has lost its importance while its essence has vanished, but there are still many people who consider themselves dandies. They can be thought of as very demanding consumers on the elegant clothing market, with certain features of postmodern metrosexuals [Mazurek-Łopacińska 2011, Maciejewski 2014, Masi de Casanova et al. 2016]. Moreover, the development of social media has made it possible for dandies from all over the world to come closer and renew this trend, as evidenced by numerous forums and groups devoted to men's elegance [Lewis and Moital 2016, Quelhas-Brito et al. 2020, WWW2, WWW3].

\section{MATERIALS AND METHODS}

\section{Sample and data collection}

The sources for the empirical part of the article are the results of primary research, designed and carried out by the authors of the study using a standardized quantitative questionnaire. The online survey technique was used among Polish e-consumer communities of enthusiasts of elegant style. The research began in October and was completed in November 2020. Therefore, the results of the research, including the declared purchasing behaviour of respondents, could have already been influenced by the SARS-CoV-2 pandemic. Before the research, the questionnaire was piloted as to eliminate possible errors of the research tool and to assess its correctness as well as usefulness in achieving the research objectives. The final version of the questionnaire contained 21 substantive questions, covering a wide range of behaviours and characteristics to describe male consumers on the elegant clothing market, and seven demographic questions.

Due to the lack of a reliable sampling frame and large dispersion of the target group, a non-random, deliberate selection of respondents was used as the sample, reaching members of discussion groups and forums devoted to the topic of male elegance. It was expected that such groups attract modern-day dandies and gallants [including the largest Polish forum devoted to male elegance, as well as a similar discussion group on Facebook - see online website citations [WWW2, WWW4]. Adults active on such forums were eligible for the sample. Interested persons could participate in the study and leave their e-mail address so as to receive articles prepared on the basis of the collected material - almost $40 \%$ of the participants expressed interest in obtaining results. It is estimated that the invitations to participate in the research could reach up to 7,000 people.

Based on the analysis of Polish e-consumer communities, it was assessed that the number of men interested in elegant style within the Polish online network does not exceed 10,000 people. Most of them, however, cannot be considered active in the community, hence the number of actual users - those more deeply interested in the subject - would not exceed $2,000-3,000$. This would constitute only a fraction of the number of dandies that has existed at one time according to the literature, which indicates the disappearance of this trend. The sample size was therefore set at 200 units, as it provides results with a measurement error of no more than $4 \%$, with a confidence level of 0.95 . At the same time, it should be remembered that the size of the sample does not depend on the size of the population, but on the degree of its homogeneity. The more homogeneous the population (in terms of selected features), the smaller the sample size [Pietrucha and Maciejewski 2020]. 167 completely and correctly finished questionnaires were obtained and qualified for further analyses carried out with the help of the IBM SPSS Statistics 26 package.

The sample as a whole was composed only of men, among whom the median age was 25 years, the mean was 27.5 years, and the dominant was 22 years. The respondents can generally be described as relatively young; their characteristics are presented in Table 1.

Due to the relatively young age of the respondents, more than $2 / 3$ of them were unmarried. Generally, they worked in professions that require elegant attire; particularly notable were lawyers, managers, entrepreneurs and economists. The distribution of monthly earnings 
Maciejewski, G., Lesznik, D. (2021). A typology of male consumers on the men's elegant fashion market: case study of Poland. Acta Sci. Pol. Oeconomia 20 (2), 59-68, doi: 10.22630/ASPE.2021.20.2.16

Table 1. Characteristics of the research sample $(N=167)$

\begin{tabular}{|c|c|c|c|}
\hline \multirow{2}{*}{ Description } & & \multicolumn{2}{|c|}{ Research sample } \\
\hline & & in numbers & $(\%)$ \\
\hline \multirow{2}{*}{ Age } & 25 or less & 88 & 52.7 \\
\hline & 26 and more & 79 & 47.3 \\
\hline \multirow{4}{*}{ Marital status } & unmarried & 112 & 67.1 \\
\hline & married & 54 & 32.3 \\
\hline & divorced & 1 & 0.6 \\
\hline & widowed & - & - \\
\hline \multirow{4}{*}{ Education } & primary & 7 & 4.2 \\
\hline & vocational & - & - \\
\hline & secondary & 52 & 31.1 \\
\hline & higher & 108 & 64.7 \\
\hline \multirow{4}{*}{ Place of residence } & village & 18 & 10.8 \\
\hline & town to 50,000 inhabitants & 15 & 9.0 \\
\hline & town between 51,000 and 200,000 inhabitants & 27 & 16.2 \\
\hline & town over 200,000 inhabitants & 107 & 64.1 \\
\hline \multirow{5}{*}{$\begin{array}{l}\text { Monthly earnings relative } \\
\text { to the national average }\end{array}$} & significantly lower & 40 & 24.0 \\
\hline & lower & 34 & 20.4 \\
\hline & roughly equal & 18 & 10.8 \\
\hline & higher & 41 & 24.6 \\
\hline & significantly higher & 34 & 20.4 \\
\hline \multirow{2}{*}{$\begin{array}{l}\text { Form of interest in an } \\
\text { elegant style }\end{array}$} & non-dandy & 118 & 70.7 \\
\hline & dandy & 49 & 29.3 \\
\hline
\end{tabular}

Source: Collected by the Authors.

compared to the national average was relatively even, more than half of the respondents had an income equal to or lower than the average wage in the Polish economy in September 2020: PLN 5,371.56 EUR 1,220 [WWW1]. The percentage of people describing themselves as dandies should be noted - in the sample dandies constituted slightly less than $30 \%$ of participants. The obtained results are therefore in contradiction to theoretical literature considerations which indicate the obliteration of dandyism at the end of the 20th century.

\section{Measures}

In order to find answers to the research questions, a scale designed especially for the needs of the research was used. It was a seven-point ordinal scale covering 13 different criteria for selecting elegant clothes (Table 3). The number 7 on the scale meant that the given criterion is very important for the respondent, while the number 1 meant that it is completely unimportant.
The reliability of the scale was confirmed by the Cronbach's alpha test. The obtained result was 0.893 . Therefore, if we assume that the acceptable level of the $\alpha$ coefficient $>0.7$, as proposed by Nunnally and Bernstei [Henson 2001], the scale used in the study can be considered reliable. The reliability of the scale should be understood as the accuracy of the obtained measurement. Its reliability informs to what extent the items included in the scale are similar to each other, whether they measure the same phenomenon, specifically the same construct. In other words, reliability is the accuracy of the measurement given by the scale, the consistency of the items included in a given construct.

Cluster analysis - of which numerous applications in consumer behaviour research are described, among others, by Walesiak [2004, pp. 344-347] was used to distinguish relatively homogeneous groups (types) of respondents due to their selection criteria for elegant clothing. Work on the described typologies was car- 
Maciejewski, G., Lesznik, D. (2021). A typology of male consumers on the men's elegant fashion market: case study of Poland. Acta Sci. Pol. Oeconomia 20 (2), 59-68, doi: 10.22630/ASPE.2021.20.2.16

ried out according to three stages proposed by Kusińska [2009, 88-89]:

- stage I - adopting the typology criteria, i.e. selecting a set of diagnostic variables on the basis of which the typology will be carried out;

- stage II - delimitation, i.e. grouping of households according to the adopted diagnostic criterion, using cluster analysis;

- stage III - assessment and versification of the obtained results, as well as elaboration of profiles of the identified clusters, taking into account active and descriptive variables (social, economic and demographic characteristics).

To carry out the typology, a measuring scale, mentioned earlier, was used. The types of the respondents were distinguished in two steps. The first was the Ward (hierarchical) cluster analysis applied with the square of the Euclidean distance, the second was the non-hierarchical $k$-means cluster analysis. The use of both methods results from methodological limitations [Gatnar and Walesiak 2009, pp. 407-421]. Non-hierarchical analysis is less sensitive to abnormal observations and incorrect variables, which leads to better results. However, it requires specifying the target number of distinguishing groups of units, which is not predetermined. To obtain this information, a hierarchical cluster analysis should be used first [Piekut 2017]. The analysis of an agglomeration coefficient and a dendrogram, obtained by means of the stratified analysis using the Ward method, led to the selection of three types of consumers (the first clear jump in the agglomeration distance, cut-off point 10). After conducting non-hierarchical analysis, their centroids (centers of gravity) were finally determined and each object was assigned to the group whose centroid is closest to it [Everitt et al. 2011], then the distinguished types were given subjective names that best reflect the behavioural characteristics of the participants assigned to given types. As a result, a typology of consumers was obtained according to 13 diagnostic variables.

\section{RESULTS}

As a result of the conducted analyses, three relatively homogeneous types of consumers were distinguished. The size of types (the number of observations in each type) and their names are presented in Table 2.
Table 2. Distinguished types of surveyed consumers

\begin{tabular}{lccc}
\hline $\begin{array}{l}\text { No. of } \\
\text { cluster/ } \\
\text { /Type }\end{array}$ & Name & $\begin{array}{c}\text { Number of } \\
\text { occurrences }\end{array}$ & $\begin{array}{c}\text { Percent of } \\
\text { occurrences }\end{array}$ \\
\hline I & exacting sartorialists & 30 & 18.0 \\
\hline II & phonies & 55 & 32.9 \\
\hline III & low-budget gallants & 82 & 49.1 \\
\hline
\end{tabular}

Source: Collected by the Authors.

The respondents who found themselves in the first of the distinguished clusters could be described as exacting sartorialists. All respondents in this cluster considered fabric composition and a product's fit to the figure as important criteria for choosing an elegant outfit. In the case of the remaining criteria, the percentage of answers "important" was the highest among the respondents from all the created clusters. The only exception was the price. In this case, the highest importance was given by the respondents forming the third cluster (Table 3). For the exacting sartorialists, it was the smallest cluster. In the sample, they constitute $18 \%$ of all respondents (Table 2).

Exacting sartorialists more often than the other types declared that they prefer fewer products, but more expensive and higher-quality ones (over 83\%). They also agreed most often with the view that dandyism and metrosexuality are closely related (almost $1 / 3$ ) - Table 4.

In turn, the respondents forming the second cluster of consumers can be considered almost the opposite of consumers from the first cluster. The vast majority of them did not pay attention to any of the criteria listed on the scale. Most often, among the selected groups, they also marked the first three answers on the scale. They constituted nearly $1 / 3$ of all respondents (Table 2). One could describe them as phonies. Phonies declare interest in elegant clothing, belong to thematic discussion groups, and at the same time do not consider criteria such as the quality of tailorship, fabric composition or fit to the figure as important (Table 3). While they most often declared active participation in forums and groups devoted to elegant style (nearly $27 \%$ ), they cared least about the quality of clothing (14\%).

The respondents from the third cluster could be described as low-budget gallants. Generally, all of the criteria for choosing an elegant outfit listed on the 
Maciejewski, G., Lesznik, D. (2021). A typology of male consumers on the men's elegant fashion market: case study of Poland. Acta Sci. Pol. Oeconomia 20 (2), 59-68, doi: 10.22630/ASPE.2021.20.2.16

Table 3. Characteristics of the types of surveyed consumers according to their preferred criteria for choosing elegant clothing and accessories $(N=167$, in \%)

\begin{tabular}{|c|c|c|c|c|}
\hline \multirow{2}{*}{ Specification } & \multirow{2}{*}{ Answer } & \multicolumn{3}{|c|}{ Type of customers } \\
\hline & & I & II & III \\
\hline \multirow{3}{*}{ Price } & important & 72.0 & 6.7 & 81.8 \\
\hline & neutral & 18.3 & 6.7 & 9.1 \\
\hline & unimportant & 9.8 & 86.7 & 9.1 \\
\hline \multirow{3}{*}{ Product brand } & important & 56.4 & - & 28.0 \\
\hline & neutral & 16.4 & - & 13.4 \\
\hline & unimportant & 27.3 & 100.0 & 58.5 \\
\hline \multirow{3}{*}{ Fabric composition } & important & 100.0 & 6.7 & 92.7 \\
\hline & neutral & - & 26.7 & 4.9 \\
\hline & unimportant & - & 66.7 & 2.4 \\
\hline \multirow{3}{*}{ Producer of the fabric used } & important & 72.7 & - & 14.6 \\
\hline & neutral & 18.2 & 10.0 & 32.9 \\
\hline & unimportant & 9.1 & 90.0 & 52.4 \\
\hline \multirow{3}{*}{$\begin{array}{l}\text { Weight, weave and other properties } \\
\text { of the fabric used }\end{array}$} & important & 85.5 & - & 62.2 \\
\hline & neutral & 10.9 & 23.3 & 25.6 \\
\hline & unimportant & 3.6 & 76.7 & 12.2 \\
\hline \multirow{3}{*}{$\begin{array}{l}\text { Sartorial details that resemble bespoke } \\
\text { tailoring }\end{array}$} & important & 78.2 & - & 30.5 \\
\hline & neutral & 18.2 & 10.0 & 18.3 \\
\hline & unimportant & 3.6 & 90.0 & 51.2 \\
\hline \multirow{3}{*}{ Product cut and style } & important & 98.2 & - & 89.0 \\
\hline & neutral & 1.8 & 30.0 & 3.7 \\
\hline & unimportant & - & 70.0 & 7.3 \\
\hline \multirow{3}{*}{$\begin{array}{l}\text { Tailoring construction used (e.g. in the case } \\
\text { of blazers - half canvas/full canvas/fused) }\end{array}$} & important & 94.5 & - & 69.5 \\
\hline & neutral & 3.6 & 13.3 & 17.1 \\
\hline & unimportant & 1.8 & 86.7 & 13.4 \\
\hline \multirow{3}{*}{ Quality of tailorship } & important & 96.4 & - & 76.8 \\
\hline & neutral & 3.6 & 16.7 & 14.6 \\
\hline & unimportant & - & 83.3 & 8.5 \\
\hline \multirow{3}{*}{ Overall fit } & important & 100.0 & 10.0 & 91.5 \\
\hline & neutral & - & 16.7 & 8.5 \\
\hline & unimportant & - & 73.3 & - \\
\hline \multirow{3}{*}{ Country of production } & important & 43.6 & - & 9.8 \\
\hline & neutral & 18.2 & - & 13.4 \\
\hline & unimportant & 38.2 & 100.0 & 76.8 \\
\hline \multirow{3}{*}{ Product environmental friendliness } & important & 34.5 & 3.3 & 8.5 \\
\hline & neutral & 34.5 & - & 11.0 \\
\hline & unimportant & 30.9 & 96.7 & 80.5 \\
\hline \multirow{3}{*}{$\begin{array}{l}\text { Opinions about the product found on forums, } \\
\text { discussion groups }\end{array}$} & important & 67.3 & - & 35.4 \\
\hline & neutral & 25.5 & 6.7 & 20.7 \\
\hline & unimportant & 7.3 & 93.3 & 43.9 \\
\hline
\end{tabular}

Note: The respondents marked their answers on a seven-point scale, where 7 - meant a very important criterion, and 1 - a completely unimportant criterion. The "important" category was created from the combination of answers marked on the scale as 5,6 and 7 , while the "unimportant" category from the combination of answers marked on the scale as 3,2 and 1. The answers marked as 4 created the "neutral" category.

Source: Collected by the Authors. 
Maciejewski, G., Lesznik, D. (2021). A typology of male consumers on the men's elegant fashion market: case study of Poland. Acta Sci. Pol. Oeconomia 20 (2), 59-68, doi: 10.22630/ASPE.2021.20.2.16

Table 4. Characteristics of the types of surveyed consumers according to declared preferences and behaviour $(N=167$, in $\%)$

\begin{tabular}{|c|c|c|c|c|}
\hline \multirow{2}{*}{ Specification } & \multirow{2}{*}{ Answer } & \multicolumn{3}{|c|}{ Type of customers } \\
\hline & & $\mathrm{I}$ & II & III \\
\hline \multirow{3}{*}{$\begin{array}{l}\text { Declared participation in forums, groups } \\
\text { or associations gathering enthusiasts of } \\
\text { elegant style }\end{array}$} & participate very actively & 23.6 & 26.7 & 12.2 \\
\hline & neither this or that & 25.5 & 30.0 & 22.0 \\
\hline & do not participate at all & 50.9 & 43.3 & 65.9 \\
\hline \multirow{3}{*}{ Preferences as to elegant products } & fewer things, but more expensive and of higher quality & 83.6 & 68.3 & 80.5 \\
\hline & neither this or that & 12.7 & 16.7 & 13.4 \\
\hline & more things, but lower in price and quality & 3.6 & 14.0 & 6.1 \\
\hline \multirow{3}{*}{$\begin{array}{l}\text { Declared period of use of the } \\
\text { purchased elegant garment }\end{array}$} & for many seasons & 94.5 & 96.7 & 97.6 \\
\hline & neither this or that & 3.6 & 3.3 & 2.4 \\
\hline & only for one season & 1.8 & - & - \\
\hline \multirow{3}{*}{$\begin{array}{l}\text { Opinions on the relationship between } \\
\text { contemporary dandyism and metrosexual } \\
\text { aesthetics }\end{array}$} & dandyism and metrosexuality are closely related & 30.9 & 26.7 & 29.3 \\
\hline & neither this or that & 27.3 & 13.3 & 11.0 \\
\hline & dandyism and metrosexuality do not coincide in any way & 41.8 & 60.0 & 59.8 \\
\hline
\end{tabular}

Note: The respondents marked their answers on a seven-point scale, where 7 - meant, respectively: I participate very actively/fewer things, but more expensive and of higher quality/for many seasons/dandyism and metrosexuality are closely related, and 1 - respectively: I do not participate/more things, but of lower price and quality/only for one season/dandyism and metrosexuality do not coincide in any way. Responses marked with 4 - were considered in opposition to both extreme categories and marked "neither this or that".

Source: Collected by the Authors.

scale are important to them, but they often remain neutral as well - in this group the greatest number of neutral answers among all the types was found. Only one criterion is considered important by the low-budget gallants more often than the amongst respondents from the other two clusters: price. Price was considered an important criterion by nearly $82 \%$ of the respondents from the third cluster, $72 \%$ of the respondents from the first cluster and less than $7 \%$ from the second cluster (Table 3). Consumers in the third cluster form the most numerous of the identified groups. In the studied sample, they are nearly half of respondents (Table 2). This may prove great growth potential of the Polish clothing market in the segment of elegant clothes.

Consumers forming the third cluster are the least likely to engage in discussions on forums or other thematic groups. Nearly $2 / 3$ of them declare that they do not undertake any such activities.

\section{DISCUSSION}

Taking the above into account, the contemporary trends of dandyism and elegance can be considered in terms of sartorialism - keen interest in tailorship and in high- quality products that respect the traditional cannons of elegance. The modern dandy is actually a sartorialist at best and a well-informed consumer with some metrosexuality. In the characteristics of the elegant types of the distinguished types, however, there are differences that distinguish modern elegant men from metrosexuals. The most elementary is the apparent preference for classic clothes, while metrosexuality is more burdened with postmodern casualization of dress, as well as a significant influence of fashion. The largest number of self-proclaimed dandies was identified within the phonies (40\%). However, when it comes to elegance, they are ignorant, whose interest in this subject may fade as quickly as it began. Interestingly, at the same time, they are characterized by the highest activity in the community among the distinguished types.

Consumers from the low-budget gallants group stand at the higher level of sartorial initiation. These people already have elementary knowledge about male elegance, they are actually interested in it and want to develop further in this area. They are willing and seek knowledge, albeit more passively (relatively less active in the community). The main problem for them is budget constraints, but on the other hand, it is thanks 
to them that they can better rationalize their expenses - they become familiar with the product, pay attention to details and look for sensible compromises within their budget, trying to make the most rational choice possible. They can generally be considered as young professionals at the beginning of their career path.

The exacting sartorialists are at the highest level of initiation to the world of male elegance. These were primarily respondents with an established professional position, generally older and wealthier. They are expected to be more conservative in their purchasing decisions, as they have already defined their tastes, and put high-quality first. Elegance in their version is more discreet - their clothes do not have to stand out as a way of trying to prove something. In this group, $29.1 \%$ of respondents considered themselves dandies.

Regardless of the cluster in question, the issues of environmental friendliness of the selected products were rather unimportant for most respondents. In part, it can be argued that high-quality elegant products are intended to serve for years, which already makes them at least partly pro-ecological. The same applies to the country of production - it plays a relatively small role, provided that the quality of the product is impeccable. Considering the opinions of the respondents as to the degree of connection of dandyism and metrosexuality, it is not surprising that phonies avoid such a classification the most; perhaps they want to emphasize their "otherness". Surveyed gallants stand in opposition to fast fashion trends and frequently changing collections. Therefore, gallants search for uniqueness, but mainly in terms of products' quality and classic style.

\section{CONCLUSIONS}

The presented research was conducted on 167 Poles interested in male elegance, which is a thriving market niche focused on quality, knowledge of the principles of tailorship and self-development. The obtained results suggest that the environment of contemporary gallants cannot be considered homogeneous. As a result of the conducted research, three groups of consumers were identified within the market of male elegant clothing. Consumers from the low-budget gallants and exacting sartorialists groups can be considered well-informed and eager to learn more, so clothing brands cannot disregard their knowledge and experience by offering low-quality products. As a contrast, respondents from the phonies cluster do not attach much importance to any of the supposedly important factors that should characterize elegant products, even to price in itself.

Contemporary elegance focuses primarily on the longevity of clothes and personal relationships with the brand, that ought to be based on mutual respect and a common history of cooperation. Brands on the elegant clothing market should therefore pay special attention to sustaining relationships with their customers. At the same time, a large number of gallants are relatively young and face significant budget constraints, so brands should consider reasonable compromises in their product lines, as to take into account this group of recipients as well. However, the limitations of the study should be borne in mind. Modern-day dandies and gallants constitute a scattered niche which is difficult to reach, hence a deliberate selection was made. A relatively small sample was limited only to elegant men from Poland. The niche itself is not too deep, but very dynamic and with high potential for further development.

It should be noted, that in the research sample no "real" dandies were identified, as according to the classic definition of this trend (research question H1). When it comes to elegant products, the surveyed gallants primarily look for higher quality, more long-lasting clothes that stand out from the crowd above all in terms of cut and the tradition of the tailoring trade (H2). At the same time, within the identified types, prosumerist and slow fashion tendencies are visible, fitting into the trends characteristic for the postmodern era (H3).

For the purposes of further research on the niche of male elegance, it is necessary to conduct more extensive research on respondents from other countries, which would allow the identification of similarities and differences of gallants on an international scale. An interesting prospect is to conduct an in-depth interview (IDI) or focus group interview (FGI) with gallants and self-proclaimed dandies, as to gain a deeper understanding of their needs, and thus provide additional recommendations for brands operating in the men's elegance segment. The authors of this article 
invite other researchers to conduct similar studies in their countries, especially on larger and representative samples. At the same time, the authors would be pleased to share the research tool used and declare their readiness to undertake joint research.

\section{REFERENCES}

Burton, T. (2017). Narrative Dandyism: The Theology of Creation in the French Decadent-Dandyism Novel 1845-1907. Trinity College, University of Oxford, Oxford.

D’Hamilton, C. (2015). Dandyism: Beyond Fashion. Greater Bay Area Costumers. Retrieved from https://www. gbacg.org/costume-resources/original/articles/dandy. pdf [accessed 15.03.2021].

Everitt, B.S. Landau, S., Leese, M., Stahl, D. (2011). Cluster Analysis, 5th Edition, Wiley Series in Probability and Statistics. John Wiley and Sons Ltd., London.

Ferrero-Regis, T. (2017). Twenty-first century dandyism: Fancy Lycra (R) on two wheels. Annals of Leisure Research 21(1), 95-112.

Gatnar, E. Walesiak, M. (Eds) (2009). Statystyczna analiza danych z wykorzystaniem programu R. Wydawnictwo Naukowe PWN, Warszawa.

Gautrand, P. (2011). Bespoke as the Staging of a Garment: a Contemporary Roman Case Study. Fashion \& Luxury: Between Heritage \& Innovation, Conference Proceedings, 133-136.

Gębala, P. (2008). Metroseksualizm: ponowoczesna kultura narcyzmu. Horyzonty Wychowania 7(13), 93-114.

Gheorghe, M. (2015). From Dandyism to Metrosexuality Between Context and Content. Retrieved from https:// ssrn.com/abstract=3296528 [accessed 15.03.2021].

Gill, M. (2007). The myth of femaly dandy. French Studies 61(2), 167-181.

Goeller, D. (2014). Portrait of a Gentleman-Swenking and the Re-Actualization of Dandyism in South Africa. South African Fashion Cultures. Retrieved from https://www.researchgate.net/publication/305467987 Portrait_of_a_Gentleman_-_Swenking_and_the_Reactualization_of_Dandyism_in_South_Africa [accessed 04.01.2021].

Halligan, B. (2011). Metrosexual. Encyclopedia of Consumer Culture, Sage. Retrieved from https://usir.salford. ac.uk/id/eprint/22608/ [accessed: 15.03.2021].

Henson, R.K. (2001), Understanding internal consistency reliability estimates: A conceptual primer on coefficient alpha (methods, plainly speaking). Measurement and Evaluation in Counseling and Development 34(3), 177-189.
Howells, B. (1996). Baudelaire: Individualism, Dandyism and Philosophy of History. Legenda, European Humanities Research Centre, Routledge, London, New York.

Khabeer, S.A. (2017). Muslim Dandies. Anthropology News (Special Issue: Fashion) 58(5), 47-54.

Lewis, A., Moital, M. (2016). Young professionals' conspicuous consumption of clothing. Journal of Fashion Marketing and Management 20(2), 138-156, https://doi. org/10.1108/JFMM-04-2015-0034

Ma, F., Shi, H., Chen, L., Luo, Y. (2012). A Theory on Fashion Consumption. Journal of Management and Strategy 3(4), 84-92.

Maciejewski, G. (2012). The Contemporary Consumer in the Face of Megatrends in Consumption. [In:] A. Olejniczuk-Merta (Ed.), The Transformation of Consumption and Consumer Behaviour. IBRKK, Warsaw, 27-42.

Maciejewski, G. (2014). Zachowania konsumentów w dobie postmodernizmu. Marketing i Rynek 8, 1129-1135.

Maciejewski, G., Lesznik, D. (2020). Dandyism - A New Trend on the Fashion Market or just a Blast from the Past? The 35th IBIMA 12(1), 9082-9090.

Masi de Casanova, E. Wetzel, E.E. Speice, T.D. (2016). Looking at the label: White-collar men and the meaning of "metrosexual". Sexualities 19(1/2), 64-82.

Mazurek-Łopacińska, K. (2011). Postmodernistyczna kultura konsumpcyjna w kształtowaniu popytu i stylów życia współczesnego konsumenta. Konsumpcja i Rozwój 1, 47-57.

Nalewajska, L. (2010). Moda męska w XIX i na początku XX wieku: fashionable, dandys, elegant. Wydawnictwa Uniwersytetu Warszawskiego, Warszawa.

Okulicz-Kozaryn, R. (1995). Mała historia dandyzmu. Obserwator, Poznań.

Pietrucha, J. Maciejewski, G. (2020), Precautionary Demand for Cash and Perceived Risk of Electronic Payments. Sustainability 12(19), 7977, https://doi.org/10.3390/ su12197977

Przybylski, R. (1986). Gentleman i dandys. [In:] M. Janion, M. Zielińska (Eds), Style zachowań romantycznych. Propozycje i dyskusje sympozjum Warszawa 6-7 grudnia 1982 r. Państwowy Instytut Wydawniczy, Warszawa,

Quelhas-Brito, P. Brandão, A. Gadekar, M. and CasteloBranco, S. (2020). Diffusing fashion information by social media fashion influencers: understanding antecedents and consequences. Journal of Fashion Marketing and Management 24(2), 137-152, https://doi. org/10.1108/JFMM-09-2019-0214

Rhodes, S.A. (1928). Baudelaire's Philosophy of Dandyism. The Sewanee Review 36(4), 387-404.

Skucha, M. (2012). Męskości nowoczesne? Wiek XIX. WIELOGŁOS, Pismo Wydziału Polonistyki UJ, 1(11), 7-20. 
Smith, T.S. (1974). Aestheticism and Social Structure: Style and Social Network in the Dandy Life. American Sociological Review 39(5), 725-743.

Szul, E. (2013). Prosumpcja jako aktywność współczesnych konsumentów-uwarunkowaniai przejawy. Nierówności społeczne a wzrost gospodarczy 31, 347-358.

Visser, J. (2011). The Dandy as an Innovator: the Usefullness of Paradoxes. Fashion \& Luxury: Between Heritage \& Innovation, Conference Proceedings, 182-186.

Walesiak, M. (Ed.) (2004), Metody statystycznej analizy wielowymiarowej w badaniach marketingowych. Wy- dawnictwo Akademii Ekonomicznej im. Oskara Langego we Wrocławiu, Wrocław.

[WWW1] Retrieved from https://en.wiktionary.org/wiki/ sartorial\#English [accessed 15.03.2021].

[WWW2] Retrieved from https://forum.butwbutonierce.pl/ [accessed 15.03.2021].

[WWW3] Retrieved from https://www.styleforum.net/ [accessed 15.03.2021].

[WWW4] Retrieved from https://www.facebook.com/ groups/Jak.bedzie.z.Dandysami [accessed 21.03.2021].

\section{TYPOLOGIA KONSUMENTÓW NA RYNKU MĘSKIEJ MODY ELEGANCKIEJ: PRZYPADEK POLSKI}

\section{STRESZCZENIE}

Autorzy prezentowanego artykułu przeprowadzili wstępne badania wśród współczesnych polskich galantów, mające na celu zidentyfikowanie typów konsumentów w niszy eleganckiej odzieży męskiej, w tym ewentualnych dandysów. Badania zostały przeprowadzone techniką ankiety online w listopadzie 2020 roku. Kwestionariusze zostały zamieszczone na forach internetowych i grupach tematycznych skupionych na polskich smart dresserach dla mężczyzn. W wyniku przeprowadzonej typologii wyróżniono trzy typy klientów: prawdziwi eleganci, niskobudżetowi galanci i pozoranci. Różnica między pierwszymi dwoma typami wynika głównie z dysproporcji ich budżetów zakupowych. Pozoranci natomiast wydają się powierzchowni w swoich decyzjach zakupowych. Być może ich zainteresowanie eleganckim stylem jest tylko ich chwilową fanaberią. Uzyskane wyniki badań powinny zainteresować właścicieli marek z segmentu męskiej elegancji, z uwagi na głęboką charakterystykę wyodrębnionych grup klientów rynku męskiej elegancji. Ponadto, w przeciwieństwie do literatury przedmiotu, badania pokazują, że dandyzm jest wciąż żywym trendem: blisko $1 / 3$ badanych uważała się za dandysów.

Słowa kluczowe: zachowania konsumentów, moda męska, trend, dandyzm, galant 